\title{
Influence of the Probiotic Lactobacillus acidophilus NCFM and Lactobacillus rhamnosus HN001 on Proteolysis Patterns of Edam Cheese
}

\author{
Marek Aljewicz ${ }^{1 *}$, Grażyna Cichosz ${ }^{1}$, Beata Nalepa ${ }^{2}$ and Marika Kowalska ${ }^{1}$ \\ ${ }^{1}$ Department of Dairy Science and Quality Management, Faculty of Food Science, \\ University of Warmia and Mazury in Olsztyn, Oczapowskiego 7, PL-10-719 Olsztyn, Poland \\ ${ }^{2}$ Department of Industrial and Food Microbiology, Faculty of Food Sciences, \\ University of Warmia and Mazury, Plac Cieszyński 1, PL-10-726 Olsztyn, Poland
}

Received: March 23, 2014

Accepted: July 31, 2014

\begin{abstract}
Summary
The objective of this study is to determine the viability of Lactobacillus acidophilus NCFM and Lactobacillus rhamnosus HN001 in Edam cheese as well as the effect of probiotic bacteria on paracasein proteolysis and changes in the water activity during ripening. The use of probiotics L. rhamnosus HN001 and L. acidophilus NCFM in Edam cheese slightly changed its chemical composition, but the change was not significant. The $\mathrm{pH}$ values were significantly correlated with the changes in Lactobacillus count $(\mathrm{R}=-0.807)$ and the level of phosphotungstic acid-soluble nitrogen compounds in total nitrogen (PTA-SN/TN) ( $R=0.775)$. After 10 weeks of ripening, the highest level of trichloroacetic acid-soluble nitrogen compounds in total nitrogen (TCA-SN/TN) was observed in the cheese containing L. rhamnosus HN001 (11.87\%) and slightly lower level in the cheese containing L. acidophilus NCFM $(7.60 \%)$ and control cheese $(6.24 \%)$. The highest level of PTA-SN/TN fraction was noted in cheese containing L. acidophilus NCFM (3.48 \%) but the lowest level was observed in control cheese $(2.24 \%)$ after ten weeks of ripening. The changes in the levels of PTA-SN/TN $(\mathrm{R}=-0.813)$ and TCA-SN/TN $(\mathrm{R}=-0.717)$ fractions were significantly $(\mathrm{p}<0.05)$ correlated with the viability of probiotic counts. Water activity $\left(a_{\mathrm{w}}\right)$ strongly correlated with the PTA-SN/ TN level $(\mathrm{R}=-0.824)$ and bacteria viability $(\mathrm{R}=-0.728)$. All of the analyzed cheeses were characterized by high counts of L. rhamnosus HN001 and L. acidophilus NCFM during ten weeks of ripening.
\end{abstract}

Key words: probiotic, Lactobacillus sp., proteolysis, peptidolysis, water activity, viability, Edam cheese

\section{Introduction}

Probiotics are selected cultures of bacteria and yeast, mostly lactic acid bacteria of the genus Lactobacillus, which benefit the health of the consumer. Probiotics deliver a health-enhancing effect by limiting lactose intolerance, inhibiting the growth of pathogenic microflora, producing vitamins, reducing cholesterol levels and stimulating intestinal immunity (1). In line with FAO/WHO guidelines (2), before a bacterial strain is classified as a probiotic, its health benefits have to be demonstrated in a series of clinical trials. It is recommended that a product with a high probiotic count (approx. 6-7 log CFU/g) be consumed in quantities higher than $100 \mathrm{~g} / \mathrm{mL}$ daily (3). However, daily consumption of $100 \mathrm{~g}$ of cheese cannot be expected due to its high fat content, which is why producers are encouraged to increase the probiotic content of cheese to approx. 8-9 $\log$ CFU/g. Daily consumption of 20-25 g of cheese high in probiotics would deliver positive health effects (4). 
Probiotic effects of a product are determined by the biochemical and physiological properties of probiotic bacteria as well as the applied delivery medium. To maximize their viability, probiotic bacteria should be supplied with products whose chemical composition protects and increases the abundance of beneficial cultures. Fermented milk products are a traditional carrier of probiotic strains which are also found in other dairy products, including fermented and non-fermented frozen dairy desserts (5), powdered milk (6), fresh cheese (7) and ripened cheese $(8,9)$.

Ripened cheese is increasingly regarded as a bio-matrix for probiotics, which remain viable over prolonged periods of time. In comparison with fermented milk, cheese is characterized by a higher fat content, a higher buffering capacity, and a lower water content and activity. Cheese ripening and storage processes offer a more supportive environment for probiotics than fermented dairy products $(4,10)$.

A very important criterion, apart from the high probiotic viability, is also the sensory quality of the product. A new product on the market is required to have a high, constant sensory quality to be accepted by potential consumers. Ripened cheese sensory quality is dependent on the biochemical processes, especially during ripening. One of the most important parameters indicative of a proper technological process is lactic acid fermentation. The acidity of the cheese immediately after production depends on the growth and activity of mesophilic citrate-fermenting streptococci. Diacetyl, a by-product of fermentation, determines the typical flavour of Edam cheese, while its taste depends on the extent and depth of proteolysis, peptidolysis and fat content. Carbon dioxide is responsible for the formation of the eye. Although proteolysis range depends on the coagulant activity of the enzyme and to a lesser extent on plasmin and perhaps somatic cell proteinases, which results in the formation of large (water-insoluble) and medium-sized (water-soluble) peptides. Subsequently, the depth of proteolysis activity (the increase in the trichloroacetic acid-soluble nitrogen (TCA-SN) and phosphotungstic acid-soluble nitrogen (PTA-SN) fractions) is determined by microbial enzymes from the starter and non-starter bacteria of the cheese $(8,11,12)$. Starter cultures do not affect paracasein degradation significantly during cheese ripening. Mesophilic Lactococcus strains produce intracellular enzymes which are activated only after bacterial autolysis. Due to enzyme-substrate specificity, secondary microflora, mostly Lactobacillus bacteria, are characterized by much higher proteolytic and peptidolytic activities (11-13).

Autolysis of starter cultures, probiotic cultures and the survival of secondary microflora (including technically harmful microflora) and bacterial enzymes significantly depend on the water activity $(14)$. Water activity $\left(a_{\mathrm{w}}\right)$ is an important parameter affecting the rate of microbiological and biochemical processes and is determined mostly by water content (free water) and concentrations of soluble compounds. Similar to sodium chloride, low-molecular-mass substances produced by casein and milk fat hydrolysis also reduce water activity (15). The addition of salt and its penetration into the cheese gradually lowers water activity in the ripening process. A drop in $a_{\mathrm{w}}$ is also induced by the presence of nitrogen compounds, the products of $\alpha_{\mathrm{S}^{-}}$and $\beta$-casein proteolysis and short-chain fatty acids $(12,16)$. The results of previous research indicate that proteolysis and peptidolysis can be controlled by limiting the growth of non-starter Lactobacillus microorganisms and replacing them with probiotic bacteria. This approach results in the production of cheese with various sensory properties (11).

Most publications concerning incorporation of bacteria into cheese focus on their survival during manufacture and viability during ripening or storage, but few studies have considered the effect of their incorporation on cheese composition and biochemical changes. Besides, most studies were conducted at laboratory scale, therefore comparing or repeating the results of different studies is sometimes impossible. Production in an automatic cheese forming system (Casomatic, Obram, Olsztyn, Poland) provides more repeatable results. Furthermore, the production at industrial scale provides better microbiological quality (including viability of probiotic culture) and biochemical parameters.

For this reason, this study was performed at industrial plant $(10000 \mathrm{~L})$. The objective of this study is to determine the viability rates of Lactobacillus acidophilus NCFM and Lactobacillus rhamnosus HN001 in Edam cheese during ten weeks of ripening and the effect of probiotics on paracasein decomposition and changes in water activity levels during ripening.

\section{Material and Methods}

\section{Edam cheese manufacture}

The experimental material comprised ripened cheese produced in an industrial plant in Giżycko, Poland. Dutch-type cheese (control and experimental) was produced from $10000 \mathrm{~L}$ (each) of premium class milk, which was thermized at $65^{\circ} \mathrm{C}$ for $15 \mathrm{~s}$ and then cooled to $4{ }^{\circ} \mathrm{C}$. It was then bactofugated, pasteurized at $72.5^{\circ} \mathrm{C}$ for $15 \mathrm{~s}$ and standardized to $3.0 \%$ fat content. Afterwards, the milk was heated to $32{ }^{\circ} \mathrm{C}$ before inoculation with cheese starter culture and probiotic bacteria. The milk was combined with $3 \mathrm{~kg}$ of calcium chloride (Ciech, Warsaw, Poland), 110 $\mathrm{mL}$ of Annatto colouring agent (Ch. Hansen, Cząstków Mazowiecki, Poland), $500 \mathrm{~mL}$ of AFILACT ${ }^{\circledast}$ (Ch. Hansen), frozen cheese starter culture (CHOOZIT ${ }^{\mathrm{TM}}$ Classic 111 $(0.06 \%)$ DuPont, Poznan, Poland). Apart from Lactobacillus rhamnosus HN001 (0.028 \% by volume) or Lactobacillus acidophilus NCFM ( $0.028 \%$ by volume) (DuPont), $430 \mathrm{~mL}$ of rennet (CHY-MAX ${ }^{\circledast}, \mathrm{Ch}$. Hansen) were added directly to the batch of the experimental cheese. In experimental cheese, the probiotic was added in an amount not less than $8 \log \mathrm{CFU} / \mathrm{g}$ after the brining. The cheese sampels were brined for $24 \mathrm{~h}$ at $4{ }^{\circ} \mathrm{C}$. After brining, the cheese samples were wrapped in Cryovac ${ }^{\circledast}$ (Sealed Air, Duchnice, Poland) oxygen barrier bags and stored in a cold room under controlled conditions. The cheese was ripened for 10 weeks at $12{ }^{\circ} \mathrm{C}$ and relative humidity of $85 \%$. Each phase of the production process was in agreement with industrial standards and according to Dutch-type cheese technology. 


\section{Chemical analysis}

Grated cheese samples were analyzed in triplicate to determine their salt content using the Volhard method (17), fat content using the Van Gulik method (18) and moisture content by oven drying at $102{ }^{\circ} \mathrm{C}(17)$. The $\mathrm{pH}$ of the cheese slurry, prepared by blending $10 \mathrm{~g}$ of grated cheese with $10 \mathrm{~mL}$ of $\mathrm{H}_{2} \mathrm{O}$, was measured with a $\mathrm{pH}$ meter (Elmetron CP 501, Zabrze, Poland, electrode: Inode, Zabrze, Poland) after calibration with $\mathrm{pH}=4.0$ and 7.0 buffers (Merck, Darmstadt, Germany).

Water activity values were determined at $25^{\circ} \mathrm{C}$ using a water activity meter (Novasina, Pfäffikon, Switzerland) after reaching equilibrium at $20^{\circ} \mathrm{C}$, according to the manufacturer's instructions. The samples were brought to room temperature prior to evaluation. After 4, 6 and 10 weeks of ripening, cheese samples were analyzed to determine the $\mathrm{pH}$ and water activity. The degree of paracasein hydrolysis was investigated by determining the concentrations of total nitrogen (TN) and water-soluble nitrogen (WSN), and the fractions of trichloroactic acid-soluble nitrogen (TCA-SN/TN) and phosphotungstic acid-soluble nitrogen (PTA-SN/TN) in total nitrogen (19).

\section{Enumeration of lactic acid bacteria in Edam cheese}

Microbiological analyses were performed after brining and after 2, 4, 6, 8 and 10 weeks of ripening. A cheese sample of $10 \mathrm{~g}$ was added to $90-\mathrm{mL}$ solution $\left(40^{\circ} \mathrm{C}\right)$ of sodium citrate $(20 \mathrm{~g} / \mathrm{L}, \mathrm{POCh}$, Gliwice, Poland). Samples were homogenized in a stomacher (BagMixer 400W, Interscience, Saint Nom, France) to produce a homogenous emulsion. After sample homogenization, serial tenfold dilutions were made using the M66 solution (15 g/L, Merck, Darmstadt, Germany) as the solvent.

Total starter culture count was determined in the control and experimental cheese samples on M17 agar (Merck). Samples were incubated aerobically at $30{ }^{\circ} \mathrm{C}$ for $48 \mathrm{~h}$. Total non-starter lactic acid bacteria from genus Lactobacillus (NSLAB) were determined on Rogosa agar (Merck). The samples were incubated anaerobically at $37^{\circ} \mathrm{C}$ for 72 $\mathrm{h}$ in the AnaeroGen system (Oxoid, Poznan, Poland).

The number of L. rhamnosus cells in the cheese samples was detected on the agar consisting of (in g): sodium chloride (POCh) 35.0, agar (Merck) 15.0, rhamnose (Merck) 10.0, neopeptone (BTL, Łódź, Poland) 10.0, meat extract (BTL) 10.0, $\mathrm{CH}_{3} \mathrm{COONa} 3 \mathrm{H}_{2} \mathrm{O}$ (POCh) 5.0, yeast extract (BTL) 4.0, triammonium citrate (POCh) 2.0, sodium phosphate (POCh) 2.0, Tween 80 (Merck) 1.2, $\mathrm{MgSO}_{4} \cdot 7 \mathrm{H}_{2} \mathrm{O}$ (POCh) 0.2 and $\mathrm{MnSO}_{4} \cdot 4 \mathrm{H}_{2} \mathrm{O}$ (POCh) 0.05 . The $\mathrm{pH}$ was adjusted to $\mathrm{pH}=(5.8 \pm 0.1)$. All these ingredients were dissolved in distilled water and sterilized by autoclaving at $118^{\circ} \mathrm{C}$ for $15 \mathrm{~min}$. After melting and cooling, it was supplemented with filter-sterilized vancomycin to $30 \mu \mathrm{g} / \mathrm{mL}$. Samples were incubated anaerobically at $37^{\circ} \mathrm{C}$ for $72 \mathrm{~h}$ with the use of the AnaeroGen system (Oxoid). The viability of Lactobacillus acidophilus cells was determined according to the method described previously (20).

The isolated strains that met the initial classification criteria for the genus Lactobacillus were subjected to a PCR analysis with the aim of identifying the genus and the spe- cies of L. acidophilus NCFM and L. rhamnosus HN001 bacteria.

\section{Isolation and identification of genomic DNA}

In order to confirm that the bacteria belong to the genus Lactobacillus and species L. rhamnosus and L. acidophilus, five randomly selected bacterial colonies were collected. Then, the material from the collected colonies was grown in MRS broth at $37{ }^{\circ} \mathrm{C}$ for $24 \mathrm{~h}$ under anaerobic conditions. Bacterial cells were centrifuged and suspended in $100 \mu \mathrm{L}$ of $10 \mathrm{mM}$ Tris-HCl buffer $(\mathrm{pH}=8.0)$. The cells were treated with lysozyme $(10 \mathrm{mg} / \mathrm{mL})$ at $37^{\circ} \mathrm{C}$ for $1 \mathrm{~h}$. Next, total genomic DNA was extracted using the Genomic Mini DNA purification kit (A\&A Biotechnology, Gdansk, Poland) according to the manufacturer's instructions. The isolated DNA was stored at $-80{ }^{\circ} \mathrm{C}$ (Kaltis, New Taipei, Taiwan) for further analyses.

The isolated strains were identified as the genus $L a c$ tobacillus by PCR using LbLMA-1-rev (5'-CTCAAAACTAAACAAAGTTTC-3') and R16-1 (5'-CTTGTACACACCGCCCGTCA-3') primers. A PCR reaction mixture $(20 \mu \mathrm{L})$ was prepared comprising $10 \mathrm{ng}$ of each primer (Oligo, Warsaw, Poland), $200 \mu \mathrm{M}$ of each nucleotide (Fermentas, Thermo Scientific, Vilnius, Lithuania), $1 \times$ PCR buffer with $2 \mathrm{mM} \mathrm{MgCl}_{2}, 1 \mathrm{U}$ of Taq polymerase (Fermentas, Thermo Scientific) and 20-40 ng of bacterial DNA. DNA fragments were amplified as follows: initial denaturation at $95^{\circ} \mathrm{C}$ for 5 min, 30 cycles consisting of denaturation at $95^{\circ} \mathrm{C}$ for 30 $\mathrm{s}$, annealing at $55^{\circ} \mathrm{C}$ for $30 \mathrm{~s}$, extension at $72{ }^{\circ} \mathrm{C}$ for $30 \mathrm{~s}$, and final extension at $72{ }^{\circ} \mathrm{C}$ for $7 \mathrm{~min}$.

Following the classification of bacterial strains as the genus Lactobacillus, they were identified at the species level with the use of specific primer pairs: Y2 (5'-CCCACTGCTGCCTCCCGTAGGAGT-3') and rham (5'-TGCATCTTGATTTAATTTTG-3') for L. rhamnosus, and 23-10C (5'-CCTTTCCCTCACGGTACTG-3') and Laci-1 (5'-TGCAAAGTGGTAGCGTAAGC-3') for L. acidophilus. The composition of the reaction mixture is described above. The PCR conditions for L. rhamnosus were as follows: 1 cycle at $95^{\circ} \mathrm{C}$ for $5 \mathrm{~min}$, at $45^{\circ} \mathrm{C}$ for $45 \mathrm{~s}$, at $72{ }^{\circ} \mathrm{C}$ for $1 \mathrm{~min}$; 30 cycles at 95 ${ }^{\circ} \mathrm{C}$ for $30 \mathrm{~s}$, at $55^{\circ} \mathrm{C}$ for $30 \mathrm{~s}$, at $72{ }^{\circ} \mathrm{C}$ for $30 \mathrm{~s} ; 1$ cycle at 95 ${ }^{\circ} \mathrm{C}$ for $5 \mathrm{~min}$, at $45^{\circ} \mathrm{C}$ for $45 \mathrm{~s}$, at $72{ }^{\circ} \mathrm{C}$ for $7 \mathrm{~min}$, and for $L$. acidophilus at $95^{\circ} \mathrm{C}$ for $5 \mathrm{~min} ; 35$ cycles at $92^{\circ} \mathrm{C}$ for $30 \mathrm{~s}$, at $68^{\circ} \mathrm{C}$ for $2 \mathrm{~min}$, at $68^{\circ} \mathrm{C}$ for $2 \mathrm{~min}$, and at $74^{\circ} \mathrm{C}$ for $5 \mathrm{~min}$.

Amplification products were visualized in $1.5 \%$ agarose gel stained with ethidium bromide $(5 \mu \mathrm{L} / \mathrm{mL})$. The anticipated size of the PCR products classified as the genus Lactobacillus was approx. $250 \mathrm{bp}$, as the species $L$. rhamnosus approx. $290 \mathrm{bp}$ and as L. acidophilus approx. 210 bp.

\section{Statistical analysis}

The results of physicochemical and microbiological analyses were evaluated for normal distribution and homogeneity of variance. The significance of differences between means or medians was analyzed by Student's $t$-test (normal distribution) or the Mann-Whitney $U$ test (abnormal distribution). Interactions between two factors were determined by ANOVA. Selected dependencies were evaluated using correlation analysis. 
The results were processed with the STATISTICA v. 10 software (StatSoft, Krakow, Poland), $\mathrm{p}<0.05, N=3$ (physicochemical and biochemical parameters); $\mathrm{p}<0.05, N=3$ (microbiological analysis, done in duplicate). Production of Edam cheese was repeated twice. All data are presented as mean values \pm standard error of the mean.

\section{Results}

\section{Chemical composition of cheese}

The control and experimental cheese samples were characterized by similar water content, from 42.9 to $43.6 \%$ (Table 1). The average protein content of control cheese was $25.83 \%$ and of experimental cheese $26.97 \%$. The analyzed cheese samples differed in their fat and sodium chloride content, but the observed differences were not significant (Table 1). The addition of the probiotic culture did not lead to significant ( $p>0.05$ ) differences in the chemical composition of the cheese.

Table 1. Composition of control and experimental Edam cheese samples

\begin{tabular}{lccc}
\hline$w / \%$ & $\begin{array}{c}\text { Control } \\
\text { cheese }\end{array}$ & $\begin{array}{c}\text { Cheese with } \\
\text { L.acidophilus } \\
\text { NCFM }\end{array}$ & $\begin{array}{c}\text { Cheese with } \\
\text { L. rhamnosus } \\
\text { HN001 }\end{array}$ \\
\hline Moisture & $(43.4 \pm 0.2)^{\mathrm{a}}$ & $(43.6 \pm 0.4)^{\mathrm{a}}$ & $(42.9 \pm 0.7)^{\mathrm{a}}$ \\
Fat & $(26.3 \pm 0.7)^{\mathrm{a}}$ & $(28.4 \pm 0.3)^{\mathrm{a}}$ & $(27.4 \pm 0.5)^{\mathrm{a}}$ \\
FDM & $(46.4 \pm 0.2)^{\mathrm{a}}$ & $(50.26 \pm 0.04)^{\mathrm{b}}$ & $(48.03 \pm 0.06)^{\mathrm{c}}$ \\
Protein & $(25.8 \pm 0.1)^{\mathrm{a}}$ & $(26.8 \pm 0.1)^{\mathrm{b}}$ & $(27.1 \pm 0.1)^{\mathrm{c}}$ \\
Salt & $(0.80 \pm 0.08)^{\mathrm{a}}$ & $(0.82 \pm 0.01)^{\mathrm{a}}$ & $(0.78 \pm 0.02)^{\mathrm{a}}$ \\
SDM & $(1.40 \pm 0.02)^{\mathrm{a}}$ & $(1.45 \pm 0.01)^{\mathrm{b}}$ & $(1.36 \pm 0.02)^{\mathrm{a}}$ \\
\hline
\end{tabular}

Analyses were conducted after brining of Edam cheese samples. Results are expressed as mean value \pm standard error of the mean. The values with the same letter in superscript do not differ significantly $(\mathrm{p}<0.05) ; \mathrm{FDM}=$ fat content in dry matter, SDM=salt content in dry matter

\section{Cheese acidity during ripening}

Immediately after brining, the average $\mathrm{pH}$ of control cheese samples was 5.22, and it was comparable to experimental cheese samples (containing L. rhamnosus HN001 and L. acidophilus NCFM), which had a $\mathrm{pH}=5.20$ (Fig. 1). The highest $\mathrm{pH}$ growth rate was observed after two weeks of ripening in all samples. Between the 2nd and the 6th week of ripening the $\mathrm{pH}$ gradually increased, and it was always higher in the control samples than in the experimental ones. A minor increase in the $\mathrm{pH}(\Delta \mathrm{pH}=0.01)$ was observed in control cheese and the cheese with L. acidophilus NCFM between the 6th and 10th week of ripening. Variations in $\mathrm{pH}$ values were significantly $(\mathrm{p}<0.05)$ correlated with changes in Lactobacillus counts $(\mathrm{R}=-0.807)$ and the content of PTA-SN/TN $(\mathrm{R}=0.775)$ fraction produced during proteolysis.

\section{Change of the water activity in Edam cheese}

Immediately after brining, the average water activity $\left(a_{\mathrm{w}}\right)$ in all cheese samples was 0.976 (Fig. 2). A slow decrease in $a_{\mathrm{w}}$ was reported in control and experimental

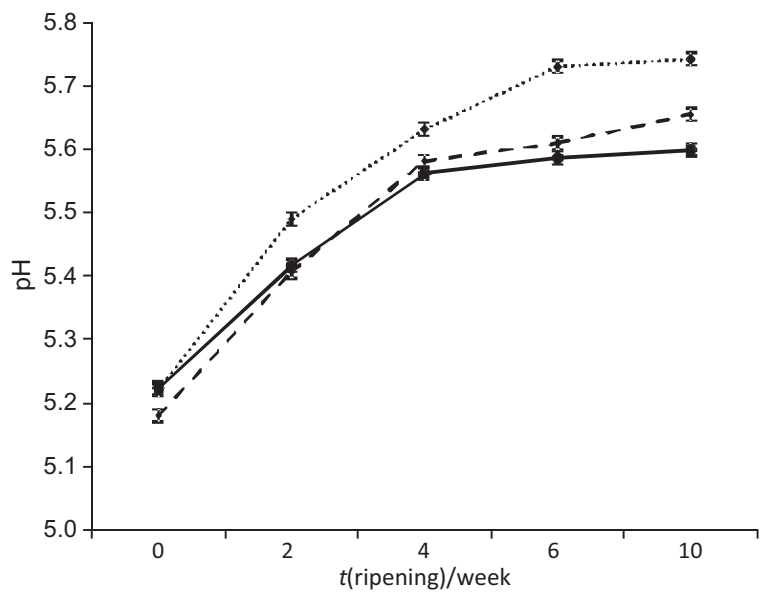

Fig. 1. Changes of $\mathrm{pH}$ during ripening of the control and experimental Edam cheese samples

$-\bullet$ control cheese, …....... potential probiotic cheese with Lactobacillus acidophilus NCFM, ---- potential probiotic cheese with Lactobacillus rhamnosus HN001

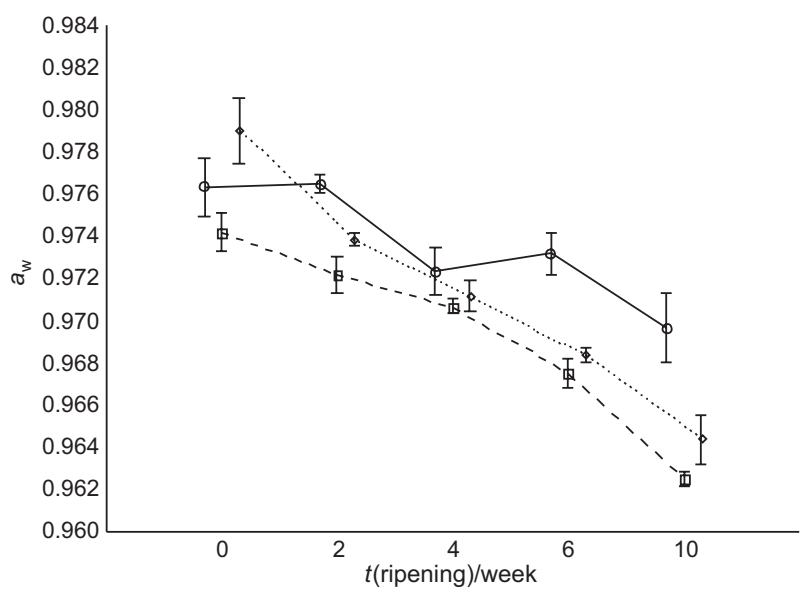

Fig. 2. Changes of water activity $\left(a_{\mathrm{w}}\right)$ during ripening of the control and experimental Edam cheese samples

$-\bullet-$ control cheese, ........... potential probiotic cheese with Lactobacillus acidophilus NCFM, -- -- potential probiotic cheese with Lactobacillus rhamnosus HN001

cheese samples during ten weeks of ripening. The water activity decreased at a faster rate in the cheese with $L$. acidophilus NCFM $\left(\triangle a_{\mathrm{w}}=0.014\right)$ and a slightly slower rate in the cheese with L. rhamnosus HN001 $\left(\Delta a_{\mathrm{w}}=0.011\right)$, whereas the slowest decrease was noted in the control cheese $\left(\Delta a_{\mathrm{w}}=0.006\right)$. The statistical analysis revealed a strong negative correlation $(R=-0.728 ; \mathrm{p}<0.05)$ between viability of probiotic bacteria and changes of $a_{\mathrm{w}}$. A negative correlation was noted between the changes in $a_{\mathrm{w}}$ and PTA-SN/TN $(\mathrm{R}=-0.824 ; \mathrm{p}<0.05)$ and TCA-SN/TN $(\mathrm{R}=-0.785 ; \mathrm{p}<0.05)$.

\section{Proteolysis and peptidolysis in Edam cheese during ripening}

The average WSN/TN fraction in control cheese samples was lower $(1.25 \%)$ than in experimental cheese samples with probiotic culture (Fig. 3). The fraction of WSN/ TN in all cheese samples increased progressively after the 
2nd week of ripening, but the increase was more intense after the 4th week of ripening period. The increase in WSN/TN fraction was higher in probiotic than in the control cheese samples. After ten weeks of ripening, the highest WSN/TN fraction was in the cheese samples with Lactobacillus rhamnosus HN001 (28.22 \%) and L. acidophilus NCFM $(26.80 \%)$ and the lowest was observed in the control $(19.50 \%)$.

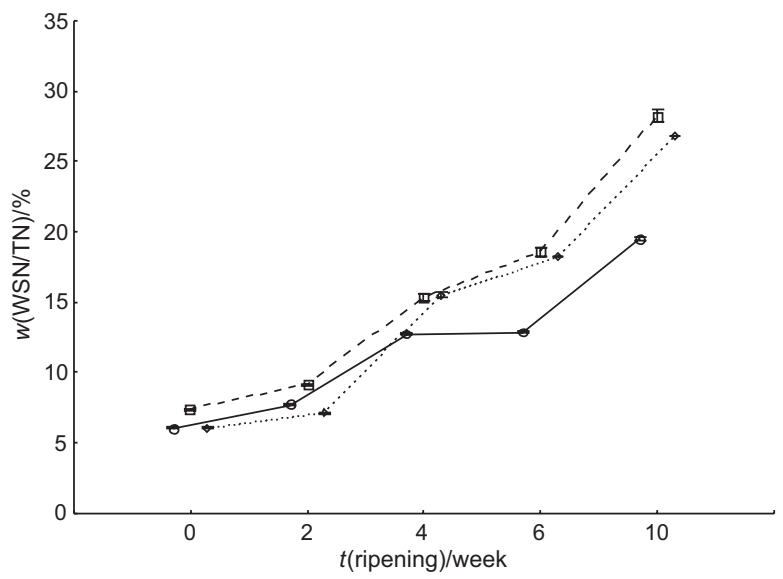

Fig. 3. Changes of water-soluble nitrogen in total nitrogen (WSN/ $\mathrm{TN}$ ) fraction during ripening of the control and experimental Edam cheese samples

$-\bullet$ control cheese, …....... potential probiotic cheese with Lactobacillus acidophilus NCFM, -- -- potential probiotic cheese with Lactobacillus rhamnosus HN001

Immediately after brining, the average TCA-SN/TN fraction in the experimental cheese samples was comparable, which was approx. $1.64 \%$, and was lower than in the control $(2.08 \%)$. After two weeks of ripening, the increase in TCA-SN/TN was low (approx. $0.50 \%$ ) in all analyzed cheese samples (Fig. 4). A gradual increase in TCA$-\mathrm{SN} / \mathrm{TN}$ fraction was observed between the 2nd and 10th week of ripening and the TCA-SN/TN fraction of the experimental cheese samples increased at a faster rate. After ten weeks of ripening, the fastest increase in TCA-SN/TN fraction was found in the cheese with L. rhamnosus HN001 $(655 \%)$ and a slightly lower increase $(520 \%)$ in the cheese with $L$. acidophilus NCFM. The lowest increase dynamics in TCA-SN/TN was found in the control cheese samples $(300 \%)$. The changes in the TCA-SN/TN values were significantly correlated with the viability of Lactobacillus sp. bacteria $(\mathrm{R}=-0.717 ; \mathrm{p}<0.05)$.

The PTA-SN/TN fraction of the analyzed cheese samples directly after brining ranged from 0.63 to $0.75 \%$. A slow increase in the PTA-SN/TN fraction was reported in the control and experimental cheese samples during ten weeks of ripening (Fig. 5). The lowest increase of PTA-SN/TN fraction was observed after two weeks of ripening (control: $0.36 \%$, L. rhamnosus HN001: $0.23 \%$, L. acidophilus NCFM: $0.07 \%)$. From the 2 nd to the 10 th week of ripening, the increase in PTA-SN/TN fraction was faster in the cheese with strains NCFM and HN001, whereas the slowest increase was reported in the control cheese. After ten weeks of ripening, the highest PTA-SN/TN fraction was observed in the cheese samples with the added strains NCFM (3.48 \%) and HN001 (3.13\%), but the lowest was

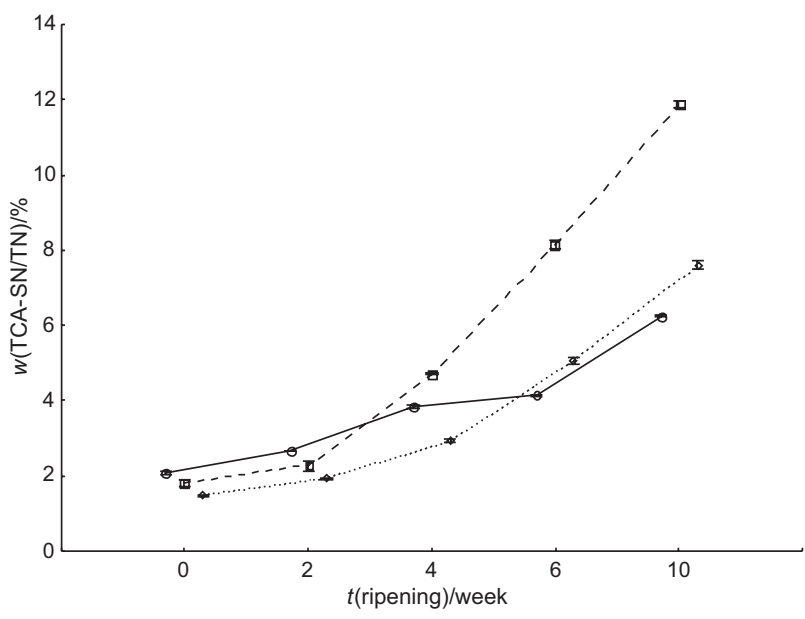

Fig. 4. Change of trichloroacetic acid-soluble nitrogen in total nitrogen (TCA-SN/TN) fraction during ripening of the control and experimental Edam cheese samples

$-\bullet-$ control cheese, …....... potential probiotic cheese with Lactobacillus acidophilus NCFM, -- -- potential probiotic cheese with Lactobacillus rhamnosus HN001

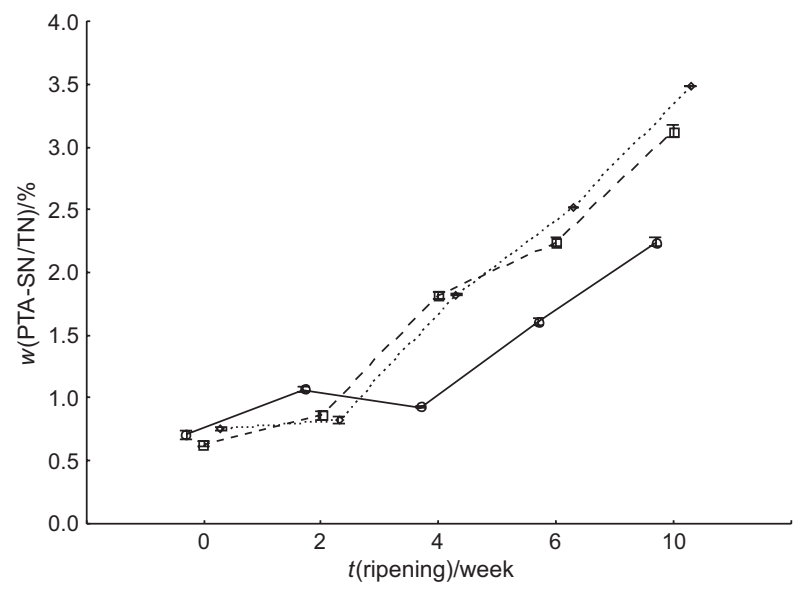

Fig. 5. Changes of phosphotungstic acid-soluble nitrogen in total nitrogen (PTA-SN/TN) fraction during ripening of the control and experimental Edam cheese samples

$-\bullet-$ control cheese, ........... potential probiotic cheese with Lactobacillus acidophilus NCFM, -- -- potential probiotic cheese with Lactobacillus rhamnosus HN001

in the control cheese (2.24\%). The changes in PTA-SN/TN values were significantly correlated with the viability of probiotic counts $(\mathrm{R}=-0.813$; $\mathrm{p}<0.05)$.

\section{Viability of lactic acid bacteria in Edam cheese}

After brining, the average Lactococcus sp. counts in experimental cheese samples were determined at $8.64 \mathrm{log}$ $\mathrm{CFU} / \mathrm{g}$ and were significantly $(\mathrm{p}<0.05)$ lower than in control cheese (8.80 log CFU/g) (Fig. 6). A gradual increase of Lactococcus sp. was noted between the 2nd and the 4th week of ripening (control: $0.54 \log \mathrm{CFU} / \mathrm{g}$, strain HN001: $0.58 \log \mathrm{CFU} / \mathrm{g}$, and strain NCFM: $0.51 \log \mathrm{CFU} / \mathrm{g})$. A gradual drop of Lactococcus sp. count was noted between the 6 th and the 10th week of ripening. Changes in the $\mathrm{pH}$ value during ripening occurred due to the production of lactate and the proliferation of non-starter lactic acid bac- 


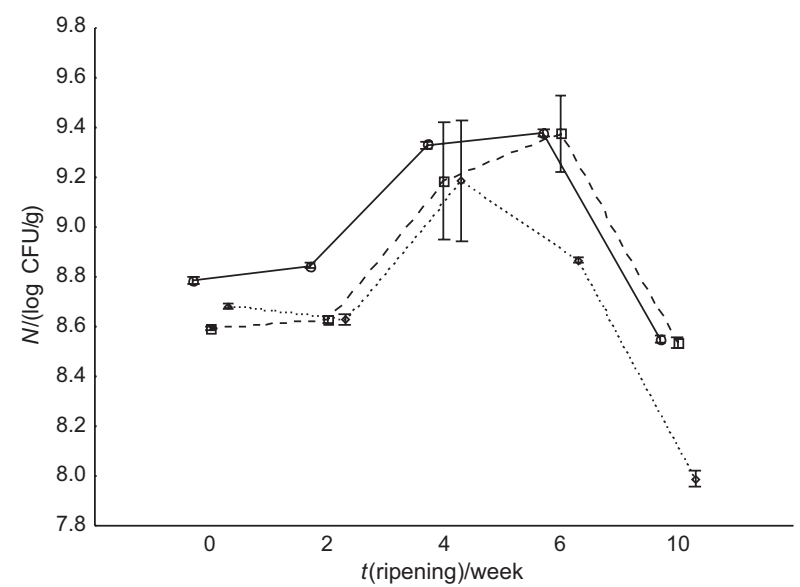

Fig. 6. Viable counts $(N)$ of Lactococcus sp. in Edam cheese samples during ten weeks of ripening

$-\bullet$ control cheese, …...... potential probiotic cheese with Lactobacillus acidophilus NCFM, -- -- potential probiotic cheese with Lactobacillus rhamnosus HN001

teria (NSLAB). For this reason, changes in Lactobacillus sp. counts were analyzed in this research. The average Lactobacillus sp. counts in the control cheese samples were determined at $3.16 \log \mathrm{CFU} / \mathrm{g}$ and were significantly $(\mathrm{p}<0.05)$ lower than in the experimental cheese samples (approx. $8.3 \log$ CFU/g) (Fig. 7). A significant increase (approx. 4 $\log$ CFU/g) in Lactobacillus sp. count was observed in the control cheese samples after four weeks of ripening. A significant (approx. $1 \log \mathrm{CFU} / \mathrm{g}$ ) reduction of probiotic bacteria population was observed in the analyzed experimental cheese samples between the 2 nd and the 4 th week of ripening. The viability of probiotic bacteria remained stable in all experimental cheese samples from the 4th week. A significant $(p<0.05)$ decrease (approx. $0.78 \log C F U / g)$ in Lactobacillus sp. count was observed in the control cheese samples after ten weeks of ripening.

Randomly selected 50 characteristic Gram-positive colonies of L. rhamnosus (25) and L. acidophilus (25) were screened by PCR, and $99.9 \%$ of the isolated strains were classified as L. rhamnosus or L. acidophilus (Figs. 8 and 9).

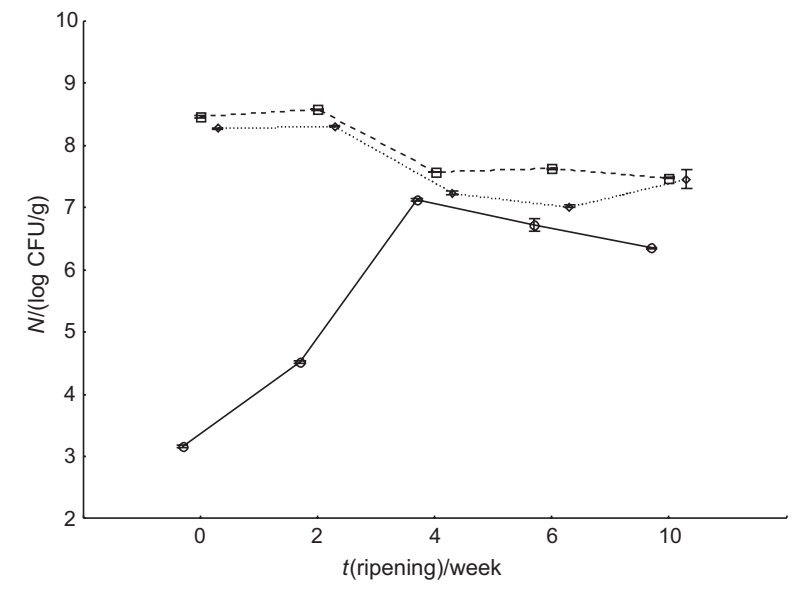

Fig. 7. Viable counts $(N)$ of Lactobacillus sp. in Edam cheese samples during ten weeks of ripening

- - control cheese, …...... potential probiotic cheese with Lactobacillus acidophilus NCFM, -- -- potential probiotic cheese with Lactobacillus rhamnosus HN001

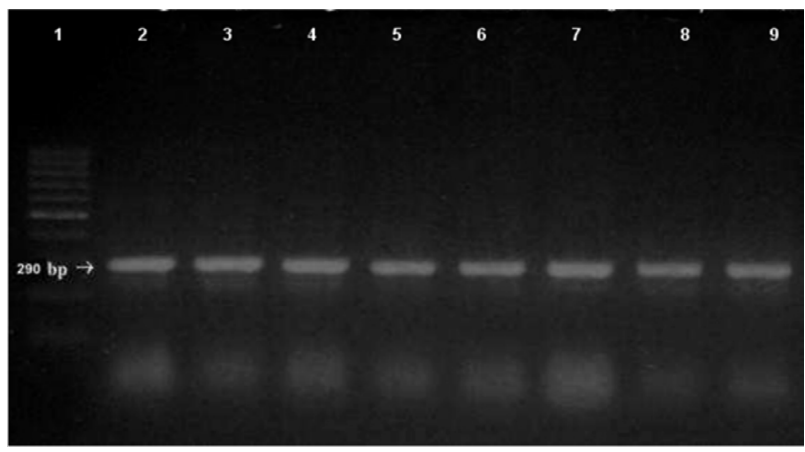

Fig. 8. PCR products (approx. $290 \mathrm{bp}$ ) amplified with the rham and $\mathrm{Y} 2$ primers. Lane 1: approx. 100-1000 bp DNA ladder; lanes 2 to 9: isolates $1 R, 2 R, 3 R, 4 R, 6 R, 7 R, 8 R$ and $11 R$

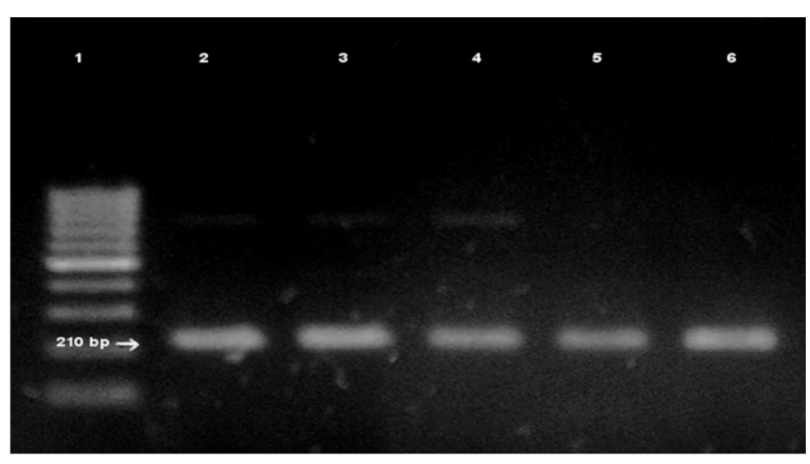

Fig. 9. PCR products (approx. $210 \mathrm{bp}$ ) amplified with the Laci-1 and $23-10 C$ primers. Lane 1: $100-1000$ bp DNA ladder; lanes 2 to 6 : isolates $6 \mathrm{~A}, 7 \mathrm{~A}, 8 \mathrm{~A}, 9 \mathrm{~A}$ and $13 \mathrm{~A}$

\section{Discussion}

The chemical composition of all ripened cheese samples was influenced mainly by the production process. The production of cheese with an identical chemical composition is practically impossible. Cheeses produced with the use of traditional methods using the same ingredients differ in their water content by approx. $1 \%$, on average. The dry matter content of cheese is also influenced by the production process: acidification, coagulation, dehydration (cutting the coagulum, cooking, stirring, pressing, salting and other operations that promote gel syneresis), shaping (moulding and pressing) and brining. According to Van den Berg et al. (21), the chemical composition of cheese can be influenced by its microbiological quality. The results of the current study confirm the above observation. The use of the probiotic culture in the production of Edam cheese changes its chemical composition. Cheese samples were characterized by a higher protein and fat content than the control cheese samples, but the differences were not significant. In contrast to our research, other authors reported that Lactobacillus sp. had no significant effect on the chemical composition of Cheddar (22), semi-hard (23) or soft cheese (24). The slightly higher protein content in the experimental cheese samples could be caused by the proteolysis of whey proteins (particularly $\beta$-lactoglobulin by lactobacilli) and the incorporation of hydrolyzed forms in the curd structure.

The high survival rates of Lactobacillus sp. were largely determined by the water activity. In the first stage of the 
production process, $a_{\mathrm{w}}$ reached around 0.99 and it did not affect significantly the bacterial populations. At successive production stages, including cheese pressing and salting, water activity decreased, reducing the populations of starter cultures and Lactobacillus. This was reflected in the correlation between the changes in L. acidophilus NCFM and L. rhamnosus HN001 counts $(\mathrm{R}=-0.728$; $\mathrm{p}<0.05)$, depending on the water activity. The analyzed cheese samples were characterized by significantly higher water activity $\left(a_{\mathrm{w}}=0.976\right)$ than semi-hard cheeses investigated by other authors, who reported $a_{\mathrm{w}}$ of $0.932-0.935$, while the values noted for Gouda cheese varied in the range of $0.913-0.960$ (25). Due to a radical improvement in raw material quality and the use of bactofugation, most of the referenced cheese products had higher water content. A comparison of various types of ripened cheese suggests that the moisture is a result of higher levels of water activity. An exception to the above rule was Cheddar cheese due to its high acidity and the application of the dry salting process (26). High levels of $a_{\mathrm{w}}$ were a consequence of cheese forming, pressing in large moulds and cutting. This process shortened the salting stage and enhanced production as well as cost effectiveness. Due to the absence of a natural cheese rind, the resulting surface absorbed much more brine, thus increasing the water content of the product, water activity levels and intensifying microbiological and biochemical processes during ripening (8). The growth of culture populations increased the rate of proteolysis and raised the concentrations of low-molecular-mass peptides, which reduce water activity.

Acidity, similarly to the chemical composition of fresh cheese, determined its microbiological quality, i.e. an increase in the amount of secondary bacteria and technologically harmful microorganisms (i.e. Escherichia coli, Clostridium sp. and Enterococcus sp.). Cheese ripening involves various biochemical processes which are determined by the presence of lactic acid bacteria (LAB) and non-starter lactic acid bacteria (NSLAB) cultures. At the initial stage of ripening, an increase of LAB counts was stimulated by substrates, i.e. organic acids (lactic acid, citric acid) and sugar residues $(27,28)$. After their depletion, lactates became a source of carbon. Most LAB are capable of drawing energy from lactate oxidation, but only in the presence of oxygen (29). The increase in the mesophilic populations of Lactobacillus bacteria was closely related to the presence of lactose and probably glycomacropeptide residues from casein degradation (30). The ripening process is accompanied by the gradual autolysis of starter cultures, which leads to the isolation of cell wall components and nucleic acids - the source of substrates supporting NSLAB growth (11).

Directly after brining, cheese was characterized by desirable $\mathrm{pH}$ values (approx. 5.20). Ripening led to a gradual increase in $\mathrm{pH}$ values due to secondary fermentation whose metabolism involves lactic acid and calcium lactate, as well as the production of ammonia from amino acid catabolism, and by increasing the water-binding capacity of the curd through the fabrication of new $\alpha$-carboxylic and $\alpha$-amino groups produced during hydrolysis of peptide bonds (31).

Variations in $\mathrm{pH}$ values were significantly correlated with changes in Lactobacillus counts and similar results were reported by other authors (32). The increase in Lactobacillus sp. populations was observed during ten weeks of ripening. NSLAB cultures consist predominantly of L. plantarum, L. casei and L. brevis (33). The presence of NSLAB in cheese directly after production is a consequence of the protective properties of milk fat, which counteracts the destructive effects of pasteurization (34). The presence of Lactobacillus sp. is also associated with the protective properties of specific proteins (DnaJ and GrpE) which are responsible for the tolerance of high pasteurization temperatures (35). Various authors $(11,36,37)$ have determined the presence of NSLAB in ripened cheese as its natural microflora and they emphasized the key contribution of NSLAB to the desirable attributes of the end product.

The L. acidophilus NCFM and L. rhamnosus HN001 probiotic cultures are characterized by high viability during the production stage and ripening. A minor drop in the probiotic population was observed in all experimental Edam cheese samples. According to other authors $(9,23,37$, 38), various Lactobacillus sp. strains, including L. acidophilus, L. paracasei and Bifidobacterium bifidus, are characterized by good viability in semi-hard cheese. The presence and diversity of the available substrates (peptides, amino acids, sugars, organic acids and their salts) stimulates the viability of bacterial cultures in cheese. Moreover, probiotic bacteria counts exceeded $7 \log \mathrm{CFU} / \mathrm{g}$ at the end of ripening period, thus supporting the classification of the produced Edam cheese as potentially probiotic.

The growth of lactic acid bacteria (LAB) and nonstarter lactic acid bacteria (NSLAB) cultures significantly contributed to the degradation of $\beta$-casein. High-molecular-mass, hydrophobic peptides were produced during the hydrolysis of $\beta$-casein by plasmin and bacterial enzymes (38). The water-soluble nitrogen (WSN) fraction is a very heterogeneous complex, which includes whey proteins, high-molecular-, medium-molecular- and low-molecular-mass peptides and free amino acids. High (approx. $5 \%$ ) content of WSN/TN in cheese after brining and slightly increased content during ripening are a consequence of the action of residual coagulant, milk proteinases, somatic cell proteinases and cell envelope proteases from the cheese microflora. Additionally, the higher WSN/ TN fraction could be a result of higher plasmin activity in cheese after the removal of plasminogen inhibitors of plasmin activators from curd during the whey removal (39). Moreover, in the milk used for the production of all experimental cheese samples the somatic cell count was high: approx. 650000 (Aljewicz, unpublished data). Generally, plasmin dominates proteolysis in milk with a low amount of somatic cells, with a minor contribution from other enzymes. However, when the amount of somatic cells increases in milk, the relative activity of other enzymes is higher than the plasmin activity (40). Marino et al. (41) showed that adding somatic cells from mastitic milk to cow's milk resulted in much faster hydrolysis of $\alpha_{\mathrm{S} 1}$-casein in experimental cheese compared to control cheese, indicating accelerated proteolysis of this casein. The higher WSN/TN fraction could be a consequence of high acidity and moisture values, and these conditions are ideal for the activity of chymosin on $\alpha_{\mathrm{S} 1}$-casein (42). The increase of WSN/TN fraction during the later stage of ripening is connected with bacterial proteinases, which are extensively released via lysis of their source microflora. 
In this study, we have found that the inclusion of $L$. acidophilus NCFM and L. rhamnosus HN001 changed the peptidolysis pattern during Edam cheese ripening. TCA-SN/TN (peptides from 2 to 22 amino acids, and amino acid residues $<3000 \mathrm{Da}$ ) fraction in control and probiotic cheese samples during ripening was significantly affected by factors such as time of ripening and population of non-starter lactobacilli in control cheese and adjunct bacteria in experimental cheese samples. TCA-SN/TN fraction increased $(p<0.05)$ progressively during ripening, especially in the cheese samples with L. rhamnosus HN001. The coagulation (i.e. rennet) and bacterial enzymes (proteinases and peptidases) are responsible for the formation of some of the non-protein compounds which were precipitated with $12 \%$ TCA (43).

The fraction of PTA-SN/TN (di- and tripeptides and amino acids) was considerably higher in the experimental cheese than in the control cheese samples throughout ripening, suggesting that the peptidases of probiotic culture origin contribute significantly to the release of amino acids during ripening. The above can be attributed to high activity of cell wall proteinases and peptidases (aminopeptidases and dipeptidases) synthesized by L. acidophilus $(9,11)$. In addition to aminopeptidases synthesized by mesophilic LAB, carboxypeptidases and tripeptidases were produced by various Lactobacillus strains $(11,44)$. Starter cultures had a marginal influence on the proteolysis and peptidolysis during ripening because intracellular aminopeptidases were released only after cell autolysis. This confirms the stronger negative correlations between the viability of Lactobacillus sp. and changes in the TCA-SN/ $\mathrm{TN}(\mathrm{R}=-0.813 ; \mathrm{p}<0.05)$ and PTA-SN/TN $(\mathrm{R}=-0.717 ; \mathrm{p}<0.05)$ fractions than the correlations between the viability of $\mathrm{Lac}$ tococcus $\mathrm{sp}$. and changes in TCA-SN/TN $(\mathrm{R}=-0.225 ; \mathrm{p}>0.05)$ and PTA-SN/TN $(\mathrm{R}=-0.111 ; \mathrm{p}<0.05)$ fractions. The stimulating effect of probiotic bacteria on the abundance of TCA-SN/TN and PTA-SN/TN has been demonstrated by various authors $(9,12,45)$. In contrast to our findings regarding Edam cheese, other authors $(33,46)$ reported that Lactobacillus sp. had no significant effect on the increase in the level of water-soluble nitrogen in Cheddar cheese.

\section{Conclusions}

The use of Lactobacillus rhamnosus HN001 and Lactobacillus acidophilus NCFM in ripened cheese production led to minor changes in its chemical composition, but the changes were not significant. The cheese samples containing L. rhamnosus HNO01 or L. acidophilus NCFM were characterized by lower acidity than the control cheese samples (without probiotic cultures). The populations of probiotic cultures used in the production of ripened Edam cheese decreased by around 1 log cycle. After ten weeks of ripening, probiotic culture counts reached approx. $7 \log \mathrm{CFU} / \mathrm{g}$. The consumption of $80-100 \mathrm{~g}$ of the obtained cheese per day could deliver health benefits. A significant correlation was determined between the increase in probiotic culture counts and the drop in water activity levels. The use of $L$. acidophilus NCFM and L. rhamnosus HN001 probiotic cultures in the production of Edam cheese changed the proteolysis pattern by intensifying proteolysis and peptidolysis.

\section{Acknowledgements}

We express our thanks to the dairy plant in Giżycko (Poland) for assistance in performing the experiment. We gratefully acknowledge financial support from the MNiSW (Ministry of Science and Higher Education, Warsaw, Poland; grant no. 52807030802).

\section{References}

1. T.A. Oelschlaeger, Mechanisms of probiotic actions - A review, Int. J. Med. Microbiol. 300 (2010) 57-62. http://dx.doi.org/10.1016/j.ijmm.2009.08.005

2. Probiotic in Foods. Health and Nutritional Properties and Guidelines for Evaluation, FAO Food and Nutrition Paper 85 (2006), FAO/WHO (ftp://ftp.fao.org/docrep/fao/009/a0512e/ a0512e00.pdf) pp. 56.

3. D. Granato, G.F. Branco, A.G. Cruz, J. Assis, F. Faria, N.P. Shah, Probiotic dairy products as functional foods, Compr. Rev. Food. Sci. Food. Safety, 9 (2010) 455-470. http://dx.doi.org/10.1111/j.1541-4337.2010.00120.x

4. G. Cichosz, M. Aljewicz, B. Nalepa, Viability of the Lactobacillus rhamnosus HN001 probiotic strain in Swiss- and Dutch-type cheese and cheese-like products, J. Food Sci. 79 (2014) 1181-1188.

http://dx.doi.org/10.1111/1750-3841.12458

5. C. Soukoulis, E. Lyroni, C. Tzina, Sensory profiling and hedonic judgement of probiotic ice cream as a function of hydrocolloids yogurt and milk fat content, LWT-Food Sci. Technol. 43 (2010) 1351-1358.

6. C. Stanton, G. Gardiner, H. Meehan, K. Collins, G. Fitzgerald, P.B. Lynch, R.P. Ross, Market potential for probiotics, Am. J. Clin. Nutr. 73 (Suppl. 2) (2001) 476-483.

7. F.C.A. Buriti, J. Da Rocha, E.G. Assis, S.M.I. Saad, Probiotic potential of Minas fresh cheese prepared with the addition of Lactobacillus paracasei, LWT-Food Sci. Technol. 38 (2005) 173-180.

8. M. Aljewicz, G. Cichosz, Ł. Łaniewska-Trokenheim, M. Danowska-Oziewicz, W. Łukaszuk-Kępka, Viability of Lactobacillus paracasei Lpc-37 in Swiss-type cheese during their ripening, Zywn-Nauk Technol. Ja. 67 (2009) 7-15 (in Polish).

9. C. Bergamini, E. Hynes, C. Zalazar, Influence of probiotic bacteria on the proteolysis profile of a semi-hard cheese, Int. Dairy J. 16 (2006) 856-866.

http://dx.doi.org/10.1016/j.idairyj.2005.09.004

10. D. Granato, G.F. Branco, F. Nazzaro, A.G. Cruz, J.A.F. Faria, Probiotic dairy products as functional foods, Compr. Rev. Food Sci. Food Safety, 12 (2012) 475-485.

11. G. Cichosz, M. Kornacki, M. Giczewska, A. Konopka, Peptidase activity of some Lactobacillus strains, Zywn-Nauk Technol. Ja. 46 (Suppl.) (2006) 66-74 (in Polish).

12. G. Cichosz, A. Zalecka, M. Lenkiewicz, The influence of streptococci and lactobacilli on proteolysis in Gouda cheese, Milchwissenschaft, 58 (2003) 297-300.

13. C.N. Lane, P.F. Fox, Contribution of starter and adjunct lactobacilli to proteolysis in Cheddar cheese during ripening, Int. Dairy J. 6 (1996) 715-728. http://dx.doi.org/10.1016/0958-6946(95)00067-4

14. J. Ramírez-Nuñez, R.R. Medrano, G.V. Nevárez-Moorillón, N. Gutiérrez-Méndez, Effect of $\mathrm{pH}$ and salt gradient on the autolysis of Lactococcus lactis strains, Braz. J. Microbiol. 42 (2011) 1495-1499. http://dx.doi.org/10.1590/S1517-83822011000400036

15. S.M. Alzamora, M.S. Tapia, A. Lopez-Malo, J. Welti-Chanes: The Control of Water Activity. In: Food Preservation Techniques, P. Zeuthen, L. Bøgh-Sørensen, CRC Press, Cambridge, UK (2003) pp. 126-153. 
16. A. Marcos: Water Activity in Cheese in Relation to Composition Stability and Safety. In: Cheese: Chemistry, Physics, and Microbiology, P.L.H. McSweeney, P.F. Fox (Eds.), Chapman and Hall, London, UK (1999) pp. 439-469.

17. AOAC Official Methods of Analysis, AOAC International Gaithersburg, MD, USA (2007).

18. Cheese - Determination of Fat Content - Van Gulik Method, ISO 3433, IDF 222, International Organization for Standardisation (ISO), Geneva, Switzerland (2008).

19. Cheese and Processed Cheese - Determination of the Nitrogenous Fractions, ISO 27871, International Organization for Standardisation (ISO), Geneva, Switzerland (2011).

20. Milk Products - Enumeration of Presumptive Lactobacillus acidophilus on a Selective Medium - Colony-Count Technique at $37^{\circ} \mathrm{C}$, ISO 20128, IDF 192, International Organization for Standardisation (ISO), Geneva, Switzerland (2006).

21. G. Van den Berg, W.C. Meijer, E.M. Düsterhöft, G. Smit: Gouda and Related Cheese. In: Cheese: Chemistry, Physics and Microbiology, P.F. Fox, P.L.H. McSweeney, T.M. Cogan, T.P. Guinee (Eds.), Elsevier, London, UK (2004) pp. 103-140.

22. L. Ong, A. Henriksson, N.P. Shah, Development of probiotic Cheddar cheese containing Lactobacillus acidophilus, Lb. casei, Lb. paracasei and Bifidobacterium spp. and the influence of these bacteria on proteolytic patterns and production of organic acid, Int. Dairy J. 16 (2006) 446-456. http://dx.doi.org/10.1016/j.idairyj.2005.05.008

23. M. Aljewicz, E. Siemianowska, G. Cichosz, E. Tońska, The effect of probiotics (Lactobacillus rhamnosus HN001, Lactobacillus paracasei LPC-37, and Lactobacillus acidophilus NCFM) on the availability of minerals from Dutch-type cheese, J. Dairy Sci. 97 (2014) 4824-2831.

http://dx.doi.org/10.3168/jds.2014-8240

24. P. Burns, F. Cuffia, M. Milesi, G. Vinderola, C. Meinardi, N. Sabbag, E. Hynes, Technological and probiotic role of adjunct cultures of non-starter lactobacilli in soft cheese, Food Microbiol. 30 (2012) 45-50. http://dx.doi.org/10.1016/j.fm.2011.09.015

25. S.J. Schmidt, A.J. Fontana Jr: Water Activity Values of Select Food Ingredients and Products. In: Water Acitivity in Foods: Fundamentals and Applications, G.V. Barbosa-Cánovas, A.J. Fontana Jr., S.J. Schmidt, T.P. Labuza (Eds.), Blackwell Publishing and the Institute of Food Technologists, Ames, Iowa, USA (2008) pp. 407-420.

26. A. Marcos, M. Alcala, F. Leon, J. Fernandez-Salguero, M. Esteban, Water activity and chemical composition of cheese, J. Dairy Sci. 64 (1981) 622-626. http://dx.doi.org/10.3168/jds.S0022-0302(81)82621-5

27. B.D. Jyotia, A.K. Suresha, K.V. Venkatesha, Effect of preculturing conditions on growth of Lactobacillus rhamnosus on medium containing glucose and citrate, Microbiol. Res. 159 (2004) 35-42. http://dx.doi.org/10.1016/j.micres.2004.01.008

28. S. Skeie, A. Kieronczyk, R.M. Næss, H. Østlie, Lactobacillus adjuncts in cheese: Their influence on the degradation of citrate and serine during ripening of a washed curd cheese, Int. Dairy J. 18 (2008) 158-168. http://dx.doi.org/10.1016/j.idairyj.2007.09.003

29. P.L.H. McSweeney: Cheese Problems Solved, CRC Press, New York, NY, USA (2007). http://dx.doi.org/10.1533/9781845693534

30. E. Parente, T.M. Cogan: Starter Cultures: General Aspects. In: Cheese: Chemistry, Physics, and Microbiology, P.F. Fox, P.H.L. McSweeney, T.M. Cogan, T.P. Guinee (Eds.), Elsevier, London, UK (2004) pp. 123-149.

31. S.Q. Liu, Practical implications of lactate and pyruvate metabolism by lactic acid bacteria in food and beverage fermen- tations, Int. J. Food Microbiol. 83 (2003) 115-131. http://dx.doi.org/10.1016/S0168-1605(02)00366-5

32. S.K. Kanawjia, P. Rajesh, L. Sabikhi, S. Singh, Flavour, chemical and textural profile changes in accelerated ripened Gouda cheese, LWT-Food Sci. Technol. 28 (1995) 577-583.

33. G. Gardiner, R.P. Ross, J.K. Collins, G. Fitzgerald, C. Stanton, Development of probiotic Cheddar cheese containing human-derived Lactobacillus paracasei strains, Appl. Environm. Microbiol. 64 (1998) 2192-2199.

34. J.R. Shakeel-Ur, M. Banks, P.L.H. McSweeney, P.F. Fox, Effect of ripening temperature on the growth and significance of non-starter lactic acid bacteria in Cheddar cheese made from raw or pasteurised milk, Int. Dairy J. 10 (2000) 45-53. http://dx.doi.org/10.1016/S0958-6946(00)00022-4

35. M. De Angelis, R. Di Cagno, R.C. Huet, C. Crecchio, P.F. Fox, M. Gobbetti, Heat shock response in Lactobacillus plantarum, Appl. Environm. Microbiol. 70 (2004) 1336-1346. http://dx.doi.org/10.1128/AEM.70.3.1336-1346.2004

36. M.C. Broome, D.A. Krause, M.W. Hickey, The use of nonstarter lactobacilli in Cheddar cheese manufacture, Austr. J. Dairy Technol. 45 (1990) 67-73.

37. P.L.H. McSweeney, E.M. Walsh, P.F. Fox, T.M. Cogan, F.D. Drinan, M. Castelo- Gonzalez, A procedure for the manufacture of Cheddar cheese under controlled bacteriological conditions and the effect of adjunct lactobacilli on cheese quality, Irish J. Agric. Food Res. 33 (1994) 186-192.

38. S. Azarnia, B.H. Lee, V. Yaylayan, K.N. Kilcawley, Proteolysis development in enzyme-modified Cheddar cheese using natural and recombinant enzymes of Lactobacillus rhamnosus S93, Food Chem. 120 (2010) 174-178. http://dx.doi.org/10.1016/j.foodchem.2009.10.003

39. K. Hinz, P.M. O'Connor, B. O'Brien, T. Huppertz, R.P. Ross, A.L. Kelly, Proteomic study of proteolysis during ripening of Cheddar cheese made from milk over a lactation cycle, J. Dairy Res. 79 (2012) 176-184. http://dx.doi.org/10.1017/S0022029912000027

40. A.L. Kelly, P.F. Fox, Indigenous enzymes in milk: A synopsis of future research requirements, Int. Dairy J. 16 (2006) 707715. http://dx.doi.org/10.1016/j.idairyj.2005.10.018

41. R. Marino, T. Considine, A. Sevi, P.L.H. McSweeney, A.L. Kelly, Contribution of proteolytic activity associated with somatic cells in milk to cheese ripening, Int. Dairy J. 15 (2005) 1026-1033. http://dx.doi.org/10.1016/j.idairyj.2004.10.006

42. A.A. Hayaloglu, M. Guven, P.F. Fox, P.L.H. McSweeney, Influence of starters on chemical, biochemical, and sensory changes in Turkish white-brined cheese during ripening, J. Dairy Sci. 88 (2005) 3460-3474.

http://dx.doi.org/10.3168/jds.S0022-0302(05)73030-7

43. P.L.H. McSweeney, Biochemistry of cheese ripening, Int. J. Dairy Technol. 57 (2004) 127-144. http://dx.doi.org/10.1111/j.1471-0307.2004.00147.x

44. K. Savijoki, H. Ingmer, P. Varmanen, Proteolytic systems of lactic acid bacteria, Appl. Microbiol. Biotechnol. 71 (2006) 394-406. http://dx.doi.org/10.1007/s00253-006-0427-1

45. M.R. Corbo, M. Albenzio, M. De Angelis, A. Sevi, M. Gobbetti, Microbiological and biochemical properties of Canestrato Pugliese hard cheese supplemented with Bifidobacteria, J. Dairy Sci. 84 (2001) 551-561. http://dx.doi.org/10.3168/jds.S0022-0302(01)74507-9

46. S. McBrearty, R. Ross, G. Fitzgerald, J. Collins, J. Wallace, C. Stanton, Influence of two commercially available bifidobacteria cultures on Cheddar cheese quality, Int. Dairy J. 11 (2001) 599-610. http://dx.doi.org/10.1016/S0958-6946(01)00089-9 